\title{
Triunfo, desgraça e outros impostores: um ensaio sobre hierarquia e exclusão no esporte e nas relações internacionais
}

CDD. 20.ed. 796.05

Diego Santos Vieira de JESUS ${ }^{* * *}$
*Pontifícia Universidade Católica - Rio de Janeiro. **Universidade Federal do Rio de Janeiro.

\section{Resumo}

0 objetivo é examinar as limitações da visão cosmopolita em torno do esporte e da atuação das organizações internacionais no estímulo às atividades esportivas como meio de reconciliação social em zonas de conflito e promoção dos direitos humanos. 0 argumento central indica que o fato de viabilizar maior contato entre diferentes culturas não significa que o esporte tenha o potencial de fazer transformações de larga escala na interação com o Outro. Além disso, o estímulo à cooperação social no âmbito esportivo tem menos relação com a eliminação de hierarquias de longa data entre as diferenças e sim com a satisfação de interesses políticos e econômicos de diversos atores no sistema internacional. É possivel perceber a permanência de estruturas logocêntricas e de formas dicotômicas de pensar que marcam a linguagem e o pensamento na interação entre as relações internacionais e o esporte. As organizações internacionais - muitas dominadas por Estados autointeressados - fazem pouco para incorporar a maioria das pessoas com pouca oportunidade, e suas iniciativas de incentivo ao esporte para a paz e desenvolvimento recebem poucas verbas, são pouco planejadas e não atuam de forma a promover uma transformação efetiva e de larga escala das visões depreciativas sobre a diferença.

Unitermos: Esporte; Relações internacionais; Cosmopolitismo; Política externa; Instituições internacionais.

If you can meet with Triumph and Disaster

And treat those two impostors just the same;

(...) Yours is the Earth and everything that's in it,

And-which is more-you'll be a Man, my son! (KipLing, 1895) ${ }^{1}$.

Longe de ser uma atividade humana que se mantivesse afastada da política ou das considerações morais, o esporte - aqui definido como a extensão de atividades físicas que abarca jogos e educação física, suas modalidades competitivas e os eventos nacionais e internacionais em que os indivíduos se engajam em tais práticas - manteve uma íntima relação com a política internacional ao longo da história, embora nem sempre houvesse o reconhecimento explícito dessa interação por especialistas ou formuladores de decisão. Segundo JACKSON e HAIGH (2008, p.349-50), o esporte pode permitir o resgate do sentido de ordem, segurança e humanidade, em particular em regiôes afetadas por conflitos no mundo contemporâneo. Num contexto globalizado, também se consolidou como atividade econômica bastante lucrativa para grandes empresas transnacionais, além de favorecer o turismo e servir como veículo de "marketing" para cidades e Estados que aspiram a uma posição global mais elevada (JACKSON \& HAIGH, 2008, p.349-50). BLACK (2008) argumenta que, conforme as forças associadas à globalização pressionam governos a atuar em múltiplos níveis além dos instrumentos tradicionais de política de desenvolvimento, o apelo estratégico para sediar competições internacionais de grande e médio porte pode funcionar como um meio de fortalecer o prestígio global e ampliar a vantagem competitiva, mesmo que as perspectivas de sucesso sejam de longo prazo ou exageradas.

Grandes eventos esportivos também podem, de acordo com CORNELISSEN (2008) na sua análise da campanha da África do Sul para sediar a Copa do Mundo de Futebol de 2010, servir a um projeto maior constitutivo de nação. Eles permitiriam o ganho de 
maior visibilidade e respeito no nível externo - no caso de países do Sul, contribuiriam inclusive para convencer a comunidade internacional da obrigação moral de promover justiça e equidade em relação aos países do Sul - e a ampliação da coesão social e política na esfera doméstica. Numa dimensão cultural mais profunda, há especialistas que defendem que os intercâmbios esportivos podem conduzir à ruptura de estereótipos negativos no relacionamento com a diferença e transformar as visões sobre o Outro, redirecionando as disputas do campo de batalha para os locais de competição esportiva. Ademais, eles funcionariam como primeiros passos para o engajamento internacional de Estados isolados, trazendo a promessa de integração e cooperação global (GolDBERG, 2000, p.63). Ao examinar o caso da penetração do futebol no Japão e nas suas antigas colônias - China e Coreia do Sul -, MANZENREITER (2008) sinaliza que o esporte pode viabilizar a expressão e a negociação de ideias de identidade, poder e "status" e a mediação com a diferença. É possível também argumentar que o esporte serviu como um meio de difundir causas políticas, expressar a luta por direitos de grupos segregados e questionar hierarquias vigentes nas dimensões doméstica e internacional. Um dos casos mais emblemáticos foi a "saudação do Poder Negro" pelos velocistas norte-americanos Tommie Smith e John Carlos, respectivamente medalhistas de ouro e bronze dos $200 \mathrm{~m}$ rasos nos Jogos Olímpicos de 1968, na Cidade do México. Eles foram de pés descalços ao pódio e levantaram seus punhos fechados, cobertos por luvas negras durante a execução do hino nacional dos EUA ao receberem suas medalhas, num símbolo da luta dos afro-americanos pelos direitos civis (GOLDberG, 2000, p.64).

Em face da possibilidade do esporte de operar como uma fonte de identificação coletiva, ele também serviu como uma expressão da identidade nacional e do nacionalismo, o que permitiu sua utilização e manipulação visando à demonstração da superioridade ideológica de sistemas políticos ou Estados específicos, ao estímulo à competição internacional e à promoção da coesão interna em torno de interesses, valores e gostos particulares de grupos localizados - sendo um exemplo visível deste último fator a manipulação das vitórias brasileiras nas competições internacionais de futebol durante o regime militar a fim de estimular o nacionalismo e abafar a oposição ao regime. DONNELly (2008, p.382) sustenta que, se por um lado há quem defenda que o esporte pode desenvolver o entendimento entre os indivíduos, facilitar o diálogo entre comunidades divergentes e estimular a tolerância entre Estados, outros vêem que ele também pode operar com base em princípios de exclusão social e ser usado para promover conformidade ideológica, militarismo e intolerância em torno de conceitos ligados a gênero, raça e deficiência física. Ademais, o estímulo às atividades esportivas como meio de preparação física foi fundamental ao desenvolvimento de exércitos melhores e, como argumentam JACKSON e Haigh (2008), como um veículo de demonstração da superioridade ideológica por meio da excelência atlética em competiçōes internacionais. Em alguns casos, a necessidade de capturar a atenção mundial a partir da demonstração de valores ligados à saúde e o desejo de conquistar projeção e aceitação fizeram com que, no passado, governos estimulassem programas de desenvolvimento de anabolizantes para a melhoria do desempenho dos seus atletas, como GERRARD (2008) documenta no caso do programa estatal de desenvolvimento de esteróides anabólicos e androgênicos para a melhoria da performance dos atletas da Alemanha Oriental durante a Guerra Fria. Segundo GoldBerg (2000, p.64), os governos reconheceram a importância do esporte na promoção da saúde e do bem-estar de suas populações, mas também como uma ferramenta diplomática a partir do uso de boicotes, da propaganda política e da recusa de emissão de vistos. O século XX foi carregado de exemplos do uso do esporte por Estados a fim de validar sistemas políticos e crenças, como a tentativa de Adolf Hitler de demonstrar a superioridade ariana nos Jogos Olímpicos de Berlin em 1936 e as disputas entre EUA e URSS para demonstrar os méritos de seus modos de produção e sistemas políticos (GOLDBERG, 2000, p.64). Ademais, atores não-estatais como organizaçōes terroristas também utilizaram eventos esportivos para causar prejuízos, provocar o choque, ganhar a atenção da mídia mundial e maximizar a incerteza política, como fez o grupo palestino Setembro Negro ao sequestrar e assassinar 11 atletas israelenses durante os Jogos Olímpicos de Munique em 1972. Como lembra Toohey (2008, p.438), o terrorismo se alimenta da cultura do medo criada por uma "sociedade de risco", de forma que os eventos esportivos, atletas, espectadores e patrocinadores de competiçôes podem ser concebidos como alvos potenciais da ação terrorista. Eventos maiores podem atrair a atenção da audiência internacional e ser utilizados para disseminar formas de violência política, o que, por outro lado, pode gerar mais cooperação governamental no combate à ameaça.

Atualmente, organizações internacionais como as Nações Unidas vem procurando estimular as práticas 
esportivas na promoção da paz e na mobilização de sociedades na busca da conscientização sobre diversos temas, bem como na melhoria das condições de saúde e de educação, na geração de emprego e na promoção da tolerância e dos direitos humanos. Um exemplo de ação nesse sentido é a elaboração do relatório de 2003 da ONU, "Sport for Development and Peace: Towards Achieving the Millennium Development Goals", que levou a uma resolução da Assembleia Geral e à declaração de 2005 como o Ano Internacional do Esporte e da Educação Física (JaCKSON \& Haigh, 2008, p.351-2). Contudo, como aponta KIDD (2008), o potencial das iniciativas lideradas por organizações internacionais intergovernamentais e não-governamentais na promoção do desenvolvimento, na ajuda humanitária e na reconciliação após as guerras por meio do esporte ainda é limitado em face da dificuldade em engajar a maioria das populações das sociedades assistidas nessas iniciativas e em manter os melhores atletas e treinadores nos países menos desenvolvidos. Padrões circunscritos de atuação também podem ser observados no que diz respeito à defesa dos direitos humanos, em particular quanto ao direito de participar dos esportes e à inclusão das diferenças por meio do esporte. Donnelly (2008) sinaliza que muitos direitos não foram exercidos ou foram interpretados de maneira neocolonialista, de forma a levar à marginalização de culturas aborígenes e à criação de sistemas esportivos que enfatizam o desenvolvimento de atletas de alta performance em vez da participação de todos os cidadãos. Ademais, a inclusão das diferenças - mulheres, homossexuais, deficientes físicos e aborígenes, dentre outras - num sistema esportivo ainda caracterizado por modelos de uma sociedade branca e patriarcal ocorreu de forma irregular.

O objetivo deste artigo é examinar as limitaçōes da visão cosmopolita em torno do esporte e da atuação das organizações internacionais no estímulo às atividades esportivas como meio de reconciliação social em zonas de conflito e promoção dos direitos humanos. Defendo que o fato de viabilizar o maior contato entre diferentes culturas não significa que o esporte tenha o potencial de fazer transformações de larga escala na interação com o Outro. Além disso, o estímulo à cooperação social no âmbito esportivo tem menos relação com a eliminação de hierarquias de longa data entre as diferenças - que podem continuar existindo, mesmo que haja interação - e sim com a satisfação de interesses políticos e econômicos de diversos atores no sistema internacional. É possível perceber a permanência de estruturas logocêntricas e de formas dicotômicas de pensar que marcam a linguagem e o pensamento na interação entre as relaçôes internacionais e o esporte: mesmo havendo espaço para o compartilhamento de alguns valores comuns entre Estados e outros atores e para a mediação com a diferença, continuam operando na relação entre eles e dentro deles aparatos de exclusão em circunstâncias espaço-temporalmente específicas. Eles funcionam como um obstáculo crucial no desenvolvimento de uma identidade que reconheça efetivamente a riqueza da diferença, seja compatível com as experiências comuns compartilhadas por eles e transcenda as normas, as regras e os princípios de coexistência. As organizações internacionais - muitas dominadas por Estados autointeressados - fazem pouco para incorporar a maioria das pessoas com pouca oportunidade, e suas iniciativas de incentivo ao esporte para a paz e desenvolvimento recebem poucas verbas, são pouco planejadas, são marginais nos esforços na promoção do desenvolvimento e não atuam de forma a promover uma transformação efetiva das visões depreciativas sobre a diferença. Cumpre lembrar que o artigo traz predominantemente um trabalho de diálogo com a literatura, não um estudo de um único caso específico que lide pontualmente com a base empírica. $\mathrm{Na}$ próxima seção, apresentarei as principais discussões teórico-analíticas acerca da interação entre os esportes e as relações internacionais. A seguir, sinalizarei os constrangimentos à visão cosmopolita em torno do esporte e, antes das considerações finais, apresentarei as limitaçōes das organizações internacionais no estímulo ao esporte como meio de reconciliação social e promoção da democracia e dos direitos humanos.

\section{O esporte e as relações internacionais}

Grande parte da literatura que se debruçou sobre o estudo de esporte e relações internacionais buscou examinar como a expansão do esporte profissional e os lucros gerados pelas ligaçôes da mídia com as atividades esportivas transformaram a economia política internacional. Ademais, procurou examinar como o esporte contribui para a construção da nação e de noçôes identitárias e representou uma faceta 
importante da diplomacia internacional (BUDD \& Levermore, 2003). Cha (2008) observa que, ao mesmo tempo em que o esporte - mais precisamente, os eventos esportivos - pode gerar inovaçōes como a "diplomacia do ping-pong" desenvolvida por Richard Nixon e Mao Tse Tung, ele também pode provocar impasses sérios no relacionamento interestatal, como os motivados pela deserção de atletas. Tratando especificamente dos Jogos Olímpicos, Senn (1999) argumenta que, mais do que eventos esportivos, as Olimpíadas são um colosso político-econômico internacional, que abarca a saturação rápida da mídia, altas apostas financeiras e fortes interesses políticos de indivíduos e grupos desde o seu início na Era Moderna, em 1896. A inter-relação entre esporte e política opera em múltiplos níveis de acordo com Houlihan (1994), que, ao focar o nível internacional, verifica que o esporte pode funcionar como um veículo para a diplomacia, a disseminação de ideologias, a construção de nações, a ampliação da inserção internacional e a conquista de ganhos comerciais. Segundo Allison e Monnington (2002, p.107-11), os Estados usaram os esportes de duas maneiras fundamentais: para venderem sua imagem - tanto na busca do sucesso em alguma iniciativa como na tentativa de atingirem maior aceitação da comunidade internacional ou penalizar o comportamento que desaprovam, como visto nos boicotes de países africanos e da Comunidade Britânica ao regime sul-africano durante a "apartheid", uma alternativa estratégica de menor custo em relação a outros métodos políticos na expressão da insatisfação e da crítica. Ademais, os benefícios adquiridos com o uso do esporte na política internacional não se traduzem necessariamente em termos tradicionais de poder bruto ou controle, mas de "status" ou prestígio de nações e sociedades civis.

Outro corpo de literatura debruça-se especialmente sobre a história da interação entre esporte e relações internacionais. HARDCASTLE (2006) indica que, apesar de as origens dessa relação serem obscuras, diversas sociedades buscaram participar de diferentes competições esportivas que estimulassem o intercâmbio cultural e contribuíssem para a expressão do discurso político de seus membros, a exemplo dos antigos egípcios, gregos e romanos. Esses dois últimos, inclusive, competiam em eventos como corridas de carruagens e lançamento de dardos, contando com a participação de animais ou o uso de dispositivos mecânicos. $\mathrm{O}$ isolamento cultural pelo sistema feudal durante a Idade Média e a oposição religiosa ao uso do corpo para a diversão dificultaram o desenvolvimento do esporte organizado no Ocidente. Posteriormente, o Renascimento e o Iluminismo despertaram novamente o interesse em jogos e exercícios, e somente no século XIX foi disseminada uma vez mais a crença de que os esportes poderiam ser uma recreação útil e um meio de interação entre povos e naçôes. Com o início dos Jogos Olímpicos da Era Moderna e o desenvolvimento de sistemas atléticos intercolegiais nos EUA, formas de esporte amador se desenvolveram, e o esporte profissional trouxe um número crescente de espectadores. No século XX, eventos como os Jogos Pan-Americanos e os Jogos da Comunidade Britânica foram criados, e os esportes tornavam-se cada vez mais politizados, como demonstraram o boicote aos Jogos Olímpicos de Moscou em 1980 pelos países ocidentais e a retaliação da URSS e seus aliados quatro anos depois, nos Jogos de Los Angeles. HardCASTLE (2006) lembra que os eventos esportivos hoje trazem a chance de promoção da cultura, da política e do comércio dos Estados. Outros autores vêem como os esportes acompanham e participam do desenvolvimento de fenômenos internacionais contemporâneos, como a globalização. Miller, Lawrence, McKay e Rowe (2001) argumentam que o esporte é o aspecto mais universal da cultura popular, num momento em que atravessa as barreiras linguísticas e ultrapassa as fronteiras nacionais, atraindo espectadores e participantes numa "língua comum" de paixões e desejos. Ao mesmo tempo em que se coloca como fonte de prazer, o esporte é também parte da administração da vida cotidiana: a criação de calendários esportivos e movimentos de recreação racional e o desenvolvimento da educação física no setor público são concebidos pelos autores como formas de disciplinar populações em sociedades urbanas e industriais. Simultaneamente, o esporte se coloca como uma das principais frentes do processo de globalização, já que une comunidades dispersas e gera riqueza econômica em culturas organizadas de acordo com a burocratização e a ideologia vigentes.

Apesar da existência de obras importantes sobre esporte e relações internacionais como as citadas acima, essa literatura ainda é limitada, num momento em que a área de Relações Internacionais focou predominantemente a política de segurança, o poder bélico e as práticas diplomáticas dos Estados e se debruçou mais sobre práticas sociais e culturais entre e dentro dos países e a participação de atores não-estatais somente a partir das três últimas décadas. Como ressalta BEACOM (2000, p.1, 6-7), debates contemporâneos relacionados aos 
efeitos da globalização, a relevância de organizações internacionais não-governamentais na formulação de políticas, as implicações de movimentos transnacionais sobre a soberania dos Estados e as transformações nas relações entre identidade e espaço provocaram alterações relevantes não apenas nas formas de pensamento na disciplina de Relações Internacionais, mas no próprio desenvolvimento da interação entre o esporte e a política internacional contemporânea. A perspectiva pluralista permite observar a rede complexa de relações entre diferentes grupos de interesse na configuração da política internacional e, no caso do exame da interação entre esporte e relações internacionais, viabiliza a investigação dos papéis das organizações esportivas intergovernamentais e não-governamentais e sua capacidade de influenciar o processo de formulação da decisão estatal. Embora BEACOM (2000, p.7-9) acredite que a influência é marginal, o papel dessas organizaçôes tornou-se crescente na última década, bem como a atuação de megaempresas transnacionais associadas ao esporte. Já os realistas argumentam que, apesar do fortalecimento do papel desses atores, eles atuam apenas em contextos limitados, e os interesses políticos dos Estados ainda continuam ditando os principais desenvolvimentos do esporte nos níveis nacional e internacional. ВЕАСОМ (2000, p.7-9) lembra que, como esses outros atores não dispõem de posições independentes em relação aos Estados, são os Estados autointeressados e racionais quem determina a agenda internacional. Acrescento que os realistas vêem na evocação de um discurso cosmopolita em torno do esporte um meio de elites privilegiadas no nível internacional convencerem os atores em posiçôes relativas inferiores de que os interesses dessas elites se sobrepóem aos de toda a humanidade. A suposta "harmonia de interesses" seria, assim, um dispositivo evocado por grupos dominantes a fim de preservar seu "status quo" (CARR, 2001).

Embora as perspectivas pluralista e realista tragam "insights" interessantes sobre a natureza da interação entre esporte e política internacional e compartilhe suas visões não necessariamente excludentes sobre o maior papel das entidades não-estatais e a permanência dos Estados autointeressados como os principais atores no nível externo, elas não são suficientes para lidar com elementos socioculturais mais complexos que se manifestam no desenvolvimento do esporte num contexto de globalização. Como destaca BЕАСОM (2000, p.10), uma perspectiva mais interpretativa permite identificar que a disseminação de novas "teorias de modernização" no processo de expansão da ordem internacional levou a uma gradativa ocidentalização de nações em desenvolvimento por novas modalidades de "imperialismo cultural", cujas inclinações homogeneizantes são também transmitidas pelos esportes por meio da mídia e das corporações multinacionais e conduzem à marginalização de Estados, comunidades políticas e indivíduos específicos. Compartilho essa visão e defendo, numa perspectiva que vai além da apresentada por BEACOM (2000), que outras múltiplas hierarquias e oposiçōes ligadas a gênero, classe social, etnia e raça continuam sendo erguidas no nível internacional também por meio dos esportes, mesmo que haja simultaneamente a disseminação de um discurso inclusivo e cosmopolita em torno das práticas e dos eventos esportivos. Tais hierarquizações cristalizadas pelos esportes também cumprem um papel fundamental numa das dimensōes constitutivas dos Estados modernos e da sociedade internacional: a soberania. A preservação da integridade soberana foi possível a partir da exclusão do Outro, com a diferenciação do espaço em que a autoridade soberana é exercida e a marginalização de outros espaços, culturas e formas de vida (WALKer, 1993, 2005). Segundo Weber (1995), não há um Estado soberano "natural" justamente porque não há uma fundação "natural" da soberania; por conta disso, o Estado é "escrito" a partir de práticas discursivas que legitimem o poder e reforcem ideias que segregam a diferença presente fora dele. SHAPIRO (2004) confirma a visão de que a soberania não tem uma significação ontológica pré-estabelecida, e, por conta disso, o Estado é uma construção de práticas simbólicas. Com base em tal reflexão, argumento que o esporte "atua" visando à preservação do status ontológico e prático do próprio Estado. Em face da perpetuação de oposições e fronteiras espaciais necessárias à sobrevivência do Estado e de hierarquias que alocam identidades em tempos distintos das diferenças por conta dos interesses de múltiplos atores não-estatais, torna-se possível compreender por que o cosmopolitismo em torno do ideal esportivo pode ter alcance limitado ou mesmo ser ilusório. 


\section{A ilusão do cosmopolitismo}

GoldBERG (2000, p.66-9) argumenta que o esporte viabiliza a apreciação e o entendimento do espírito de cooperação e de competição justa, reforçando aspectos de humanidade comum às diversas comunidades políticas ao redor do planeta. Nesse sentido, abriria espaços de conversação e interação com a diferença, reconhecendo-se uma dimensão cosmopolita que permitisse a identificação e o respeito. Desde a década de 70, nações africanas e latino-americanas usaram o esporte como um meio de promoção de orgulho e solidariedade, contrastando a imagem de sucesso de seus atletas com a ideia de nações com economias e sistemas políticos falidos e pressionando nações mais desenvolvidas por maior reconhecimento dos méritos das menos abastadas. Ademais, os reconhecimentos de realizações de atletas independentemente da nacionalidade - havendo assim a possibilidade de glorificação de heróis esportivos de outros países - permitiria ao esporte atuar como um canal para maior entendimento. Uma crença cosmopolita aponta que as populaçóes poderiam substituir estereótipos acerca de adversários ou párias por visões que reconhecessem as riquezas e os méritos de outras sociedades e permitissem a construção de um discurso alternativo que impedisse o prolongamento de hostilidades, como uma possível mudança da imagem da Coreia do Norte nos EUA como um regime ditatorial e opressor pela figura celebrada do jogador de basquete norte-coreano Michael Ri (GOlDBERG, 2000, p.66-9).

Porém, o fato de permitir mais contato entre diferentes culturas não significa que o esporte tenha o potencial de provocar transformações de larga escala, em particular na visão de formuladores de decisão, mesmo porque sua recepção é distinta entre os múltiplos setores sociais e políticos e, em diversas comunidades, varia de acordo com idade, gênero, classe social e etnia. O estímulo à cooperação social no âmbito esportivo parece ter menos relação com a eliminação de hierarquias de longa data entre as diferenças - que podem continuar existindo, mesmo que haja interação - e sim com a satisfação de interesses políticos e econômicos dos atores no nível internacional. Segundo CORNELISSEN (2008, p.4812), o esporte pode funcionar como um instrumento de política visando à satisfação de necessidades e interesses domésticos e externos dos Estados. Em face dos principais desenvolvimentos da economia política internacional na contemporaneidade, os esportes se tornaram meios importantes pelos quais os Estados procuram se retratar para investidores estrangeiros e turistas, além de servirem como meios de comunicar mensagens para suas contrapartes. A instrumentalidade do esporte - em particular dos megaeventos esportivos - revela formas alternativas de condução das relações internacionais, permitindo, por exemplo, que um conjunto de Estados traduza as desvantagens econômicas e políticas em vantagens. Muitos Estados em desenvolvimento - como a África do Sul na competição para sediar a Copa do Mundo de Futebol de 2010 e o Brasil na disputa para sediar os Jogos Olímpicos de 2016 - usam recursos mais limitados a fim de competir contra nações poderosas para sediar megaeventos esportivos futuros. Em tais ocasiōes, eles exploram suas características culturais, riquezas naturais e beleza e, em nível estratégico, proclamam o "status" de "marginalizados" e "excluídos" na ordem internacional, o que faz com que possam influenciar a forma como megaeventos são vistos pelas próprias federaçôes internacionais de esporte: mais do que competiçóes esportivas, são retratados como projetos inseridos em perspectivas de desenvolvimento desses Estados. Diversos países colocam-se como representantes de regiōes específicas, buscando, assim, projetar-se como líderes de áreas onde se situam, como ficou visível na evocação do pan-africanismo pela África do Sul na campanha para sediar a Copa do Mundo de 2010 (Cornelissen, 2008, p.481-2).

Ademais, objetivos domésticos e internacionais variados podem ser atingidos por um conjunto complexo de atores, como membros de governos federais, estaduais e municipais; federações esportivas; corporações midiáticas e empresários. Neste trabalho, defendo que eles vão da busca de consolidação da inserção política e do prestígio internacional à atração de investimentos e à maximização de lucros. Porém, a alteração de visões com relação à diferença ainda se mantém um objetivo menor para grande parte desses atores, quando ainda pode ser considerado um objetivo deles. Como aponta Cornelissen (2008, p.483-4), os esportes envolvem inúmeros setores econômicos e mercados, a produção de diversos bens e a interseção de múltiplas esferas políticas dentro e fora do Estado. A popularidade de megaeventos tem forte apelo emocional, e megaempresas podem explorar as aspiraçōes sociais e as buscas individuais por novos eixos de identificação manifestos a partir do consumo. Por conta disso, companhias nacionais e transnacionais patrocinam eventos esportivos com valores comerciais crescentes e que têm efeitos não apenas sobre os ganhos de tais empresas, mas outros atores. Federações de 
esportes e o Comitê Olímpico Internacional ganham "status" como atores políticos que podem influenciar as condiçōes para o futuro econômico e até mesmo político de diversos Estados, já que diversos governos vêm definindo objetivos de desenvolvimento em torno da participação em campanhas para sediar megaeventos. Ademais, deliberaçōes das federaçōes esportivas podem refletir divisões, influência, poder e rivalidade existentes nas relações internacionais, fazendo com que essas federações sirvam como palcos para a perpetuação de hierarquias ou para a formação de coalizões que busquem combatê-las. $\mathrm{Na}$ própria organização de eventos esportivos, abremse plataformas para a cooperação entre governos de Estados visando a atingir objetivos comuns de promoção do desenvolvimento, e, no caso de países emergentes, tem-se a possibilidade de converter um conjunto limitado de recursos em capital político e diplomático na negociação com os países do Norte (Cornelissen, 2008, p.483-4). Cumpre lembrar, contudo, que o estímulo à solidariedade eà cooperação visando a atingir um objetivo comum não pressupõe a desestabilização de estereótipos em torno dos parceiros, como será mais explorado adiante.

No nível doméstico, tais governos também esperam ganhos de naturezas múltiplas com relação ao esporte e aos eventos esportivos. Campanhas para sediar eventos esportivos de médio e grande porte tornam necessária a realização de uma série de investimentos, como a construção de estradas, a modernização de estádios e o desenvolvimento de uma rede de serviços mais eficiente. Contudo, nem sempre é fácil para as lideranças desses Estados convencer uma população relutante e cética de que tais investimentos possam trazer bases para que mais investimentos sejam feitos no futuro e novas candidaturas sejam possíveis (Cornelissen, 2008, p.486). Podem ser sinalizados benefícios como a geração de empregos diretos e indiretos e o desenvolvimento de infra-estrutura e, em sociedades abaladas por históricos de exclusão e de marginalização das diferenças como a sul-africana, o desenvolvimento de maior integração entre raças e etnias diferentes, de políticas de reconciliação e de coesão nacional. A melhoria dessas condições domésticas pode ter efeitos positivos no nível internacional, permitindo maior prestígio e participação em fóruns multilaterais e a mudança da imagem do país não somente perante investidores, mas organizações de direitos humanos e instituições pautadas pela defesa de valores democráticos. Entretanto, como enfatizam AlLison e Monnington (2002, p.132), o investimento no esporte e na educação física em nível de elite e para as massas não costuma atrair muito apoio quando a infra-estrutura socioeconômica geral é precária. Os esportes podem trazer reconhecimento e prazer temporários a sociedades em crise, mas não eliminam definitivamente os efeitos de políticas e economias corruptas em colapso, e, por isso, não costumam ser prioridade para populações mais preocupadas com segurança, educação e emprego.

$\mathrm{Na}$ prática, nem sempre os efeitos positivos imaginados com a realização de grandes eventos esportivos são atingidos. Além de muitos governos acabarem contraindo dívidas enormes e terem que arcar com déficits orçamentários - como foi o caso da Grécia na construção da estrutura dos Jogos Olímpicos de Atenas de 2004 - e de contribuintes questionarem se os gastos realmente valeram a pena, um dos principais desafios para diversos governos é honrar com as "dívidas diplomáticas" adquiridas com os parceiros que os apóiam em suas iniciativas de sediar eventos esportivos. Allison e MonningTON (2002, p.130-1) apontam que os custos da realização desses eventos podem estar além das capacidades orçamentárias nacionais, o que levaria à necessidade desses países de pedirem auxílio a agências externas de financiamento a fim de implementarem os projetos e, uma vez mais, reforçarem-se imagens de neocolonialismo e dependência econômica. Em nível cultural, sinalizo que a transformação de visões depreciativas em relação à diferença é circunscrita e limitada, quando realmente acontece. Ela dificilmente ocorre em múltiplos setores sociais em face da construção social de preconceitos enraizados em relação à diferença e ainda esbarra no interesse de atores políticos em fazer do esporte um instrumento de promoção do seu poder e status. Como colocam Budd e LEVERMORE (2003), o esporte pode ser utilizado para fortalecer a visão dominante do mundo político dividido cartográfica e politicamente em Estados competidores, perpetuando uma visão que reproduz oposiçôes e hierarquias. Muitas vezes, tais Estados até mesmo utilizam meios escusos na busca de prestígio e ampliação da posição relativa. De acordo com GERRARD (2008, p.461-2), uma série de governos era dotada de programas de dopagem de atletas, o que demandava a colaboração de médicos, cientistas e especialistas em treinamento esportivo. No caso da Alemanha Oriental, essa infra-estrutura secreta era preservada com um rígido monitoramento do Estado. Drogas poderosas eram administradas aos melhores atletas a fim de melhorar sua performance, em particular as anabólicas, derivadas da testosterona e dotadas de poder de 
ampliação da massa muscular. Os efeitos colaterais da administração dessas substâncias em homens e mulheres no longo prazo foram o desenvolvimento de doenças do coração e do fígado, bem como variadas formas de câncer. Quando o escândalo do "doping" na Alemanha Oriental veio à tona, o Comitê Olímpico Internacional precisou fortalecer os mecanismos legais que limitavam o uso de drogas no esporte. Desde os Jogos Olímpicos da Cidade do México em 1968, a Comissão Médica do Comitê assumiu a responsabilidade crescente de credenciar laboratórios a fim de realizar análises de amostras de urina dos atletas e publicar a lista de substâncias banidas (GERRARD, 2008, p.461-2). Entretanto, o "doping" continua sendo uma realidade nos esportes contemporâneos, e se acredita que alguns Estados ainda mantenham programas secretos de administração de drogas em seus atletas a fim de obter melhores performances em competiçóes esportivas.

O caso da Alemanha Oriental é um exemplo de que o esporte - em particular a busca por desempenhos melhores - mostra sua função política não apenas em Estados capitalistas ocidentais e democráticos, mas até mesmo em sociedades que contam com sistemas políticos e econômicos distintos, como os comunistas. $\mathrm{Na}$ visão marxista, as instituições sociais como o esporte e a cultura física derivavam da base econômica da sociedade. Como o modo de produção determinava o caráter da vida social, o esporte e a cultura física seriam partes da superestrutura da sociedade. Além disso, como o homem muda tanto a natureza como a natureza dele mesmo, pode-se chegar à conclusão de que há uma ligação entre o trabalho e o exercício físico, ambos servindo como mecanismos promotores de mudança. Marx percebia o valor do exercício físico no desenvolvimento do indivíduo de forma harmoniosa e acreditava que o homem precisava de recreação física, de forma que a educação física deveria compor um sistema ideal de preparação junto ao treinamento intelectual e ao ensinamento das técnicas de produção. Lênin enxergava a importância da educação física no treinamento militar e na preparação para o trabalho, concebendo que o esporte seria uma força para o desenvolvimento individual harmonioso (PePpard, 1982, p.25; Riordan, 1977, p.64). Em particular na URSS, especialistas e líderes tenderam a enfatizar os aspectos práticos e utilitários das ideias marxistas-leninistas sobre cultura física e ignorar a possibilidade da atividade física pela busca de prazer. O esporte na sociedade socialista parecia diferir, assim, em estrutura organizacional e natureza fundamental daquele desenvolvido na capitalista.
Se na primeira o esporte e a cultura física tinham como objetivo o desenvolvimento de qualidades morais, éticas e estéticas do povo e a preparação para o trabalho e a defesa, o esporte competitivo na segunda era concebido como inerentemente corrupto, num momento em que era parte de um aparato socioeconômico no qual era usado como meio para explorar os indivíduos, desviar as massas do esforço de luta por justiça social e preparar as pessoas para a conquista imperialista (PEPPARD, 1982, p.25-6). Por conta disso, a URSS optou por ficar de fora do sistema de esporte internacional burguês na década de 20, condenando-o como inerentemente capitalista e explorador. O país buscou definir um sistema esportivo internacional alternativo baseado numa vertente proletária da "cultura física".

Todavia, a tentativa soviética de desenvolver um sistema doméstico e internacional coletivista de cultura física baseado na classe e orientado para as massas foi gradativamente superada pela expansão da cultura esportiva transnacional capitalista, orientada para o consumidor e centrada nas elites (KeYs, 2003, p.414-5). Segundo KeYs (2003, p.414-6), a regulação e a supervisão estatais ampliaram-se após a I Guerra Mundial, visivelmente sobre as atividades de lazer com o objetivo de desenvolver soldados e trabalhadores produtivos por meio de programas de esportes e de educação física. A participação no esporte internacional de elite tornou-se gradativamente um indicador do poder nacional, já que a competição nessa área oferecia bases para a comparação do sucesso na ampliação e na mobilização dos recursos populacionais. Allison e Monnington (2002, p.116) argumentam que a busca soviética pela vitória em competições internacionais era uma espécie de campanha por "coraçôes e mentes" a fim de não somente persuadir outros Estados a reconhecer as virtudes e a superioridade do regime comunista. Ela também era voltada para a demonstração de força e sucesso dentro das próprias fronteiras soviéticas - especialmente nas repúblicas não-russas constitutivas da união - a fim de preservar a coesão e a integridade do Estado.

Fica claro que o estímulo à cooperação esportiva no nível internacional tem menos a ver com a desestabilização e a integração das diferenças e mais com a satisfação de múltiplos interesses políticos e econômicos, o que leva a disputas acirradas por prestígio e poder que mais segregam do que promovem a aceitação do Outro na dimensão de riqueza e disseminam padrões culturais ligados ao consumo que ameaçam culturais locais. A interação entre esporte e relaçōes internacionais mostra-se predominantemente 
deletéria à promoção do cosmopolitismo não apenas no âmbito de políticas externas autointeressadas dos Estados ou das ações internacionais de grandes corporações, mas na dimensão das relações humanas cotidianas, em particular diante da disseminação da globalização. Segundo Maguire (2008, p.445), a migração intracontinental e intercontinental de atletas, treinadores e especialistas da área de esporte tornou-se cada vez mais frequente, e, nesse processo, existem claros padrōes nacionais no recrutamento desses atletas em esportes como futebol, basquete, críquete, hockey no gelo e atletismo. Nesse recrutamento, os perfis de relação com o Outro e a definição de estereótipos que definem qualidades e defeitos dos atletas vindos de diferentes países e grupos étnicos se consolidam (MAGUire, 2008, p.445, 451-2). Isso reafirma visōes simplificadas e pré-concebidas em torno da diferença e os aspectos depreciativos de tais representações limitadas.

Ademais, como indica MAGUire (2008, p.451-2), os países doadores latino-americanos e africanos podem sofrer a perda de talentos para os desenvolvidos, onde os atletas em geral recebem melhores salários e contam com melhor infra-estrutura. Os Estados menos desenvolvidos muitas vezes investem na produção de determinados talentos esportivos, mas, uma vez que eles atingem a maturidade, as ligas mais desenvolvidas economicamente em países do Norte os recrutam. Segundo Allison e Monnington (2002, p.130-1), se no passado os atletas representavam embaixadores de seus países, hoje cada vez mais se tornam produtos no mercado esportivo global e estão sujeitos a forças econômicas que requerem que eles respondam às suas necessidades. Em busca de fama e fortuna, diversos atletas deixam seus países de origem onde poderiam ser colocados como modelos para futuras gerações de esportistas, o que também limita a possibilidade de que sejam usados por líderes a fim de atingir objetivos políticos ou pessoais. $\mathrm{Na}$ sociedade receptora desses atletas, observam-se choques constantes no que diz respeito à promoção do sucesso comercial dos clubes e ao prestígio associado às seleçôes nacionais; à disputa entre aqueles que visam à criação de um espetáculo que possa ser vendido para a mídia e aqueles que defendem a identidade local e o desenvolvimento dos atletas. MAGUire (2008, p.456) sinaliza que a globalização também pode ter conduzido a uma nova onda de rivalidade étnica, nacionalismo e rejeição de outras culturas, o que incide diretamente na relação dos atletas de outras regióes do planeta com torcidas adversárias e até mesmo com as suas próprias torcidas e alimenta o preconceito. Exemplos emblemáticos da permanência das hierarquias na relação com a diferença podem ser vistos nas ofensas racistas contra jogadores de futebol latino-americanos e africanos que atuam nos campeonatos europeus por torcidas adversárias, membros das torcidas de seus próprios times e jogadores europeus de outros clubes.

\section{A superestima do papel das organizações internacionais}

Analisando a própria história do movimento olímpico, é possível observar a relação entre os esportes e a política internacional por meio do papel das organizações internacionais. Como lembra BEACOM (2000, p.12), o Barão Pierre de Coubertin reconhecia - por razões que poderiam ser puramente oportunistas - a relação do movimento com as aspirações da Liga das Nações. Desde então, uma série de organizaçôes internacionais intergovernamentais e não-governamentais tem-se empenhado em mobilizar o esporte como um veículo para o desenvolvimento social e sustentável - em particular em regiões mais pobres do planeta, como o Leste da África -, bem como o ensinamento de higiene pessoal e responsabilidade sexual à juventude, de acordo com KIDD (2008, p.370). Na antiga Iugoslávia, o UNICEF buscou utilizar escolas de futebol para conscientizar crianças e jovens acerca dos perigos representados pelas minas terrestres, enquanto ONGs como a Peace Players International promovem o ensino do basquete para estimular a comunicação entre jovens de diferentes origens étnicas e religiosas em Israel, na Irlanda do Norte e na África do Sul. A Comissão de Solidariedade Olímpica - ligada ao Comitê Olímpico Internacional deu destaque à promoção de educação e treinamento, e seus recursos financiaram a produção de manuais para administração e medicina esportivos (KIDD, 2008, p.370). Contudo, como aponta KIDD (2008, p.371-2, 375-6), os programas que buscam usar os esportes como meios de avançar na reconciliação e na comunicação intercultural em regiōes de conflito e na realização das Metas de Desenvolvimento do Milênio das Nações Unidas ainda são limitados, pois fazem pouco para engajar a maioria das pessoas com pouca oportunidade de praticar atividades esportivas. Esses programas costumam dedicar seus recursos 
aos melhores atletas e treinadores nos países menos desenvolvidos a fim de melhorem suas condições. Em grande parte dos casos, os melhores atletas são retirados de suas nações, sendo perdidos como fontes de liderança e transformação nesses locais. Apesar da profusão de programas e conferências internacionais acerca do tema, as iniciativas de esporte para a paz e desenvolvimento ainda são circunscritas, além de serem pouco reguladas e pobremente planejadas e coordenadas e estarem em posição marginal em relação aos principais esforços na promoção do desenvolvimento. Ademais, as organizações precisam da cooperação de outros atores como os governos nacionais, que poderiam prover os programas de pessoal preparado e recursos, mas poucas autoridades realmente se mostraram dispostas a fazer isso (KIDD, 2008, p.371-2, 375-6).

O papel das instituiçōes intergovernamentais em particular é limitado pela sua excessiva dependência em relação aos Estados que as criaram. MEARSHEIMER (1995) ressalta que Estados mais poderosos como as grandes potências podem criar instituiçōes a fim de manter e ampliar seu poder, ou seja, as instituições - entendidas como conjuntos de regras que estipulam as formas em que os Estados devem cooperar e competir com os outros - são regras criadas por Estados racionais, os quais escolhem racionalmente se vão obedecer ou não a tais regras que eles mesmos criaram. Assim, tais instituições apenas refletem os cálculos de auto-interesse de atores preocupados com ganhos relativos e a distribuição de poder no sistema. Justamente por não afetarem o comportamento dos Estados de forma independente e serem submissas a eles, as instituições refletem a distribuição de poder no sistema e são utilizadas instrumentalmente por Estados a fim de satisfazer seus objetivos de acordo com as circunstâncias. Na visão do autor, quando há divisão e dispersão entre os atores com mais recursos de poder, eles podem relegar tais instituiçôes em segundo plano se acreditam que outros meios podem permitir a satisfação de seus interesses fundamentais.

Num momento em que espelham os interesses de Estados racionais e egoístas, tais instituições também se mostraram limitadas na sua habilidade de promover, por meio do esporte, o reconhecimento efetivo da riqueza da diferença entre os membros e o desenvolvimento de experiências comuns compartilhadas que transcendam as normas, as regras e os princípios de coexistência. Essa dificuldade deu-se não somente entre diferentes Estados, mas dentro dos mesmos em esforços de reconciliação social pós-conflito, e se mostrou também no que diz respeito à própria redefinição do papel do esporte dentro de sociedades específicas. Em diversas delas, mais do que um meio de recreação, ele continuou sendo primordialmente visto como meio de preparação de soldados para o confronto militar e a guerra e reforçou a posição privilegiada da masculinidade hegemônica, que marginalizou mulheres e masculinidades alternativas. Mais especificamente, a guerra teve papel fundamental na definição do que significa ser "homem", tanto em nível simbólico e institucional como na definição do corpo masculino. Na dimensão simbólica, a ideia de que os homens tiram a vida enquanto as mulheres a dão reifica as diferenciações entre esses pares e, no aparato de guerra moderno, reforçou as masculinidades dos soldados e a exclusão das mulheres da situação de combate. A guerra é concebida, assim, como uma expressão completa da "agressão natural" do homem, bem como da sua urgência em proteger seu país e suas "mulheres" (HOOPER, 2001, p.81-3). Nos Estados-nação modernos, as Forças Armadas são concebidas como "escolas para a nação" que criam um ideal de "masculinidade nacional". A dureza e o sacrifício são incorporados pelos militares, de forma a fazer com que os ideais masculinos hegemônicos de coragem e bravura tornem-se o conteúdo do caráter do "cidadão-soldado", defendam-se as honras pessoal e patriótica a fim de se evitar a vergonha e se criem narrativas culturais e pessoais de incorporação de masculinidades militares pautadas na força nacional e na determinação (NyE, 2007, p.421-3). Além de o serviço militar servir como um rito de passagem para que "meninos" se tornem "homens" ao longo da era moderna, o treinamento envolve a modelagem física e social do corpo do homem por meio da educação física e do esporte, disciplinando-o, definindo seu estilo de masculinidade e seus contornos e ampliando a vigilância e a regulação sobre ele ao torná-lo "economicamente eficiente" e promover o autocontrole emocional (Hopper, 2001, p.81-3).

Segundo HiNojOSA (2010, p.179-81), as masculinidades hegemônicas estão no topo da hierarquia de gênero e existem em relação às construções subordinadas. As características mais tradicionais incluem a tomada de riscos, a autodisciplina, a dureza física, o desenvolvimento muscular e o desejo abertamente heterossexual, sendo que tais elementos são colocados em posiçōes de domínio simbólico. Muitos homens aderem ao serviço militar por conta do histórico familiar e das consideraçóes econômicas. Além disso, o serviço militar permite o acesso a recursos materiais importantes à masculinidade hegemônica, como a segurança econômica e corpos definidos e capazes 
oferecidos pelo treinamento físico e pelo esporte. No caso de Estados em posições relativas superiores na distribuição de poder nos sistemas regional e multilateral, cabe destacar que, como as identidades como as masculinidades são construídas a partir da interação entre recursos materiais e simbólicos disponíveis, as Forças Armadas tornam alguns desses recursos institucionalmente disponíveis no que diz respeito à construção de masculinidades hegemônicas, atribuindo juridicamente a tais homens o direito de usar a força letal para a manutenção da dominação política e física de outros indivíduos e Estados. No processo de definição das masculinidades dos homens soldados a partir da oposição a outros indivíduos - como os homens civis $\mathrm{e}$ as mulheres -, as narrativas enfatizam a centralidade do corpo atlético definido pelo esforço físico e pelo esporte ou a representação física, também evidentes em performances normativas fora do ambiente militar. Como MankaYi (2008, p.24-5, 32, 39-40) argumenta, a não-conformidade ao físico ideal masculino é apresentada como superável uma vez que o homem se torne um soldado. Num momento em que os termos da masculinidade requerem que os homens tenham um nível elevado de força muscular, o treinamento promovido pelo aparato militar pode permitir que eles sejam fisicamente definidos. A centralidade desse entendimento dominante do papel do esporte e da educação física permaneceu intocada na atuação de organizaçôes intergovernamentais em diversas sociedades pós-conflito, o que contribui para a permanência da marginalização, violência e intolerância.

Diversas organizaçôes internacionais também procuraram atuar visando a desenvolver formas pelas quais os direitos humanos pudessem ser alcançados e protegidos por meio do esporte, como o próprio direito a participar de atividades esportivas e o uso dos esportes para conquistar os direitos para classes específicas de indivíduos. Quanto ao direito de participar do esporte e das atividades físicas, as primeiras declaraçóes internacionais específicas surgiram na década de 70. A Carta Europeia Esporte para Todos de 1976 e a Carta Internacional de Educação Física e Educação adotada pela Conferência Geral da UNESCO em 1978 são alguns exemplos, e várias medidas de estímulo à atividade física foram tomadas pelos próprios Estados a partir dos estímulos dessas instituições, tendo em vista a possibilidade de redução de gastos estatais com saúde e de combate à obesidade. Entretanto, o sucesso desse tipo de iniciativa pelas organizaçōes internacionais foi alcançado primordialmente nos países nórdicos e em Estados com alta renda per capita. Em Estados subdesenvolvidos e em desenvolvimento, o direito de participar em esportes não atinge a todos, e os programas colocam-se de forma neocolonialista, levando à perda de culturas físicas existentes e enfatizando o desenvolvimento de esportes de alta performance em detrimento dos esportes locais, dos quais a população mais participa. Por exemplo, o uso dos fundos da Solidariedade Olímpica mostra-se orientado para sistemas ocidentais de treinamento e administração de esportes de alta performance, marginalizando as realidades socioculturais locais (DONNELLY, 2008, p.384-6). Vêse, assim, que o Ocidente continua a acreditar que tem pouco a receber e aprender com comunidades não-ocidentais ou aborígenes, e, ao contrário de se ter um diálogo ou uma cooperação que estimule o entendimento da diferença na sua dimensão de riqueza, observa-se o reforço de hierarquias que a concebem como disfuncional ou atrasada.

Padrões semelhantes de exclusão podem ser identificados no que diz respeito ao uso dos esportes pelas organizaçóes internacionais na luta por direitos de classes específicas de indivíduos. Como ressalta Donnelly (2008, p.387-8), diversos grupos marginalizados socialmente vêm contando com o apoio de instituiçôes internacionais intergovernamentais e não-governamentais na defesa de seus direitos por meio do esporte, em particular o futebol, que, por exemplo, reúne times de vítimas de minas terrestres na África Ocidental. Contudo, lembro que nem todas as realizaçóes foram suficientes para alterar a realidade de exclusão de forma significativa. Desde a Convenção sobre a Eliminação de Todas as Formas de Discriminação contra as Mulheres em 1979, o direto de mulheres e meninas de participar em atividades esportivas foi endossado, mas elas ainda continuam tendo papel marginal em termos de participação em certos esportes tidos como "masculinos" e recebem salários inferiores aos dos homens. A hostilidade à homossexualidade no cenário esportivo perpetua-se em face da contínua ligação entre modelos de masculinidade hegemônica, a heterossexualidade compulsória e a prática esportiva na construção de Estados, embora "gays" e lésbicas tenham estabelecido times e ligas esportivas e organizado os Gay Games - realizados a cada quatro anos desde 1982 - e os Out Games - realizados pela primeira vez em 2006 em Montreal - e atletas transexuais tenham sido aceitos em ligas de esportes de alta performance, como lembra Donnelly (2008, p.387-8). Os deficientes físicos e mentais passaram a participar cada vez mais dos esportes em face do incentivo aos Jogos Paraolímpicos e outras 
competições paraesportivas, mas esses atletas ainda recebem atenção marginal dos governos e patrocínio reduzido, e as organizaçōes internacionais puderam fazer pouco para reverter esse quadro. Apesar de muitos avanços, eles ainda são limitados e não foram suficientes para a desestabilização significativa de hierarquias que orientam o cenário esportivo no nível internacional.

\title{
Considerações finais
}

Não é meu objetivo desconsiderar completamente o potencial do esporte como meio de promoção da mediação com a diferença ou a atuação das organizações internacionais, mas sim evitar a superestima de seu potencial transformador em face dos obstáculos colocados por objetivos políticos e econômicos de múltiplos atores sociais e do controle das organizações internacionais por atores autointeressados - no caso das intergovernamentais, os Estados. $\mathrm{O}$ reconhecimento da diferença na sua dimensão de riqueza e a promoção de um cosmopolitismo que não seja sinônimo da expansão universal dos valores e ideais de uma comunidade específica - no caso, o Ocidente - ainda são objetivos secundários e marginais, quando são efetivamente levados em conta ou não são instrumentalizados como máscaras de interesses políticos e econômicos considerados "primordiais" ou "mais urgentes". Nesse contexto, o fato de haver mais contato entre diferentes culturas não pressupõe que o esporte possa promover transformaçōes de larga escala, e o estímulo à cooperação esportiva no nível internacional tem menos a ver com a eliminação de hierarquias entre as diferenças e sim com a satisfação de objetivos políticos e econômicos de diversos atores. Continuam intactas, assim, estruturas logocêntricas e formas dicotômicas de pensar, apesar da mediação com a diferença. A personificação do Triunfo continua centrada na própria identidade, ao passo que a Desgraça é relegada à diferença. Continuamos nos deixando envolver - e também frustrar - por discursos que impedem a reavaliação de nossas visões sobre os outros e nós mesmos.

\begin{abstract}
Triumph, disaster and other impostors: an essay on hierarchy and exclusion in sports and international relations

The aim is to examine the limitations of the cosmopolitan view on sport and the role of international organizations in fostering sports as means of social reconciliation in conflict areas and promotion of human rights. The central argument indicates that the fact of bringing greater contact between different cultures does not mean that sport has the potential to make large-scale transformations in the interaction with the Other. Furthermore, the stimulus to social cooperation in sports has less to do with the elimination of longstanding hierarchies between differences than with the satisfaction of political and economic interests of various actors in the international system. It is possible to see the persistence of logocentric and dichotomous ways of thinking that characterize language and thought in the relationship between international relations and sport. International organizations - many are dominated by self-interested states - do little to incorporate the majority of people with less opportunities, and their initiatives to encourage sport for peace and development receive little funding, are poorly designed and do not act to promote an effective and large-scale transformation of disparaging views about the difference.
\end{abstract}

UNITERMS: Sport; International relations; Cosmopolitanism; Foreign policy; International institutions. 


\section{Nota}

1. Rudyard Kipling, "If”, 1895. O poema foi lido na íntegra por Roger Federer e Rafael Nadal em um vídeo promocional feito para a final do torneio de Wimbledon em 2008.

\section{Referências}

ALLISON, L.; MONNINGTON, T. Sport, prestige and international relations. Government and Opposition, London, v.37, n.1, p.106-34, 2002.

BEACOM, A. Sport in international relations: a case for cross-disciplinary investigation. The Sports Historian, London, v.20, n.2, p.1-23, 2000.

BLACK, D. Dreaming big: the pursuit of 'second order' games as a strategic response to globalization. Sport in Society, Boston, v.11, n.4, p.467-80, 2008.

BUDD, A.; LEVERMORE, R. (Eds.). Sport and international relations: an emerging relationship. London: Routledge, 2003. CARR, E.H. The twenty years' crisis, 1919-1939. Nova York: Perennial, 2001.

CHA, V.D. Beyond the final score: the politics of sport in Asia. Nova York: Columbia University Press, 2008.

CORNELISSEN, S. Scripting the nation: sport, mega-events, foreign policy and state-building in post-apartheid South Africa. Sport in Society, Boston, v.11, n.4, p.481-93, 2008.

DONNELLY, P. Sport and human rights. Sport in Society, Boston, v.11, n.4, p.381-94, 2008.

GERRARD, D.F. Playing foreign policy games: states, drugs and other olympian vices. Sport in Society, Boston, v.11, n.4, p.459-66, 2008.

GOLDBERG, J. Sporting diplomacy: boosting the size of the diplomatic corps. The Washington Quarterly, Washington, v.23, n.4, p.63-70, 2000.

HARDCASTLE, J. Examining international relations in the realm of sports through history. Leisure and Sport Review, [S.1.], 2006. Disponível em: <http://www.lasr.net/recreationarticles.php?ID=6382>. Acesso em: 12 mar. 2011.

HINOJOSA, R. Doing hegemony: military, men, and constructing a hegemonic masculinity. The Journal of Men's Studies, Harriman, v.18, n.2, p.179-94, 2010.

HOOPER, C. Manly states: masculinities, international relations, and gender politics. Nova York: Columbia University Press, 2001. HOULIHAN, B. Sport and international politics. Hemel Hempstead: Harvester Wheatsheaf, 1994.

JACKSON, S.J.; HAIGH, S. Between and beyond politics: sport and foreign policy in a globalizing world. Sport in Society, Boston, v.11, n.4, p.349-58, 2008.

KEYS, B. Soviet sport and transnational mass culture in the 1930s. Journal of Contemporary History, London, v.38, n.3, p.413-34, 2003.

KIDD, B. A new social movement: sport for development and peace. Sport in Society, Boston, v.11, n.4, p.370-80, 2008. MAGUIRE, J. 'Real politic' or 'ethically based': sport, globalization, migration and nation-state policies. Sport in Society, Boston, v.11, n.4, p.443-58, 2008.

MANKAYI, N. Masculinity, sexuality and the body of male soldiers. Psicology in Society, Congella, n.36, p.24-44, 2008. MANZENREITER, W. Football diplomacy, post-colonialism and Japan's quest for normal state status. Sport in Society, Boston, v.11, n.4, p.414-28, 2008.

MEARSHEIMER, J.J. The false promise of international institutions. International Security, Cambridge, v.19, n.3, p.5-49, 1995.

MILLER, T.; LAWRENCE, G.A; McKAY, J.; ROWE, D. Globalization and sport: playing the world. Thousand Oaks: Sage, 2001. NYE, R.A. Western masculinities in war and peace. American Historical Review, New York, v.112, n.2, p.418-38, 2007. PEPPARD, V.E. The Soviet critique of sport and physical culture. Quest, Champaign, v.34, n.1, p.23-33, 1982.

RIORDAN, J. Sport in Soviet society: development of sport and physical education in Russia and the USSR. Cambridge: Cambridge University Press, 1977.

SENN, A.E. Power, politics, and the Olympic Games. Champaign: Human Kinetics, 1999.

SHAPIRO, M. Methods and nations: cultural governance and the indigenous subject. New York: Routledge, 2004.

TOOHEY, K. Terrorism, sport and public policy in the risk society. Sport in Society, Boston, v.11, n.4, p.429-42, 2008.

WALKER, R.B.J. Inside/outside: international relations as political theory. Cambridge: Cambridge University Press, 1993. 
JESUS, D.S.V.

. The doubled outsides of the modern international. In: INTERNATIONAL CONFERENCE ON DIVERSITY IN ORGANIZATIONS, COMMUNITIES AND NATIONS, 5., Beijing, 2005. Proceedings... Beijing: Commom Group, 2005.

WEBER, C. Simulating sovereignty: intervention, the state and symbolic exchange. Cambridge: Cambridge University Press, 1995.

\begin{tabular}{r|r} 
ENDEREço & \\
Diego Santos Vieira de J esus & \\
Instituto de Relacões Internacionais & Recebido para publicação: 13/05/2011 \\
R. Marquês de São Vicente, 225 - Vila dos Diretórios - casa 20 & Aceito: 16/06/2011 \\
22451-900 - Rio de J aneiro - RJ - BRASIL & \\
e-mail: dsvj@puc-rio.br & \\
\hline
\end{tabular}

430 • Rev. bras. Educ. Fís. Esporte, São Paulo, v.25, n.3, p.417-30, jul./ set. 2011 